\title{
Escape to the Country: A Reaction-Driven Rural Renaissance on a Swedish Island Post COVID-19
}

\author{
Hanna Elisabet Åberg *(1) and Simona Tondelli (1) \\ Department of Architecture, Alma Mater Studiorum-University of Bologna, 40100 Bologna, Italy; \\ simona.tondelli@unibo.it \\ * Correspondence: hannaelisabet.aberg@unibo.it
}

check for updates

Citation: Åberg, H.E.; Tondelli, S.

Escape to the Country: A

Reaction-Driven Rural Renaissance on a Swedish Island Post COVID-19. Sustainability 2021, 13, 12895. https:/ / doi.org/10.3390/su132212895

Academic Editors: Francesco Caracciolo and Dalia Štreimikienè

Received: 15 October 2021

Accepted: 14 November 2021

Published: 22 November 2021

Publisher's Note: MDPI stays neutral with regard to jurisdictional claims in published maps and institutional affiliations.

Copyright: (C) 2021 by the authors. Licensee MDPI, Basel, Switzerland. This article is an open access article distributed under the terms and conditions of the Creative Commons Attribution (CC BY) license (https:// creativecommons.org/licenses/by/ $4.0 /)$.

\begin{abstract}
The COVID-19 pandemic could be driving more households to migrate out of cities and to the countryside, but this might result in an increased demand for access to green space which, in the long run, may cause a widening of social inequalities in rural areas. On the contrary, if planned for, it could provide an opportunity for repopulation and regeneration. This article explores the underlying causes and impacts of current rural in-migration, and further, it touches on how planning can balance development while supporting communities for a rural renaissance. By using a case study area in Sweden, it examines evidence of amenity-driven in-migration flows before and during the pandemic. The findings show an increased usage of part-time housing as a result of demand for space and nature; however, this was made possible through already well functioning infrastructures. Acknowledging that it is crucial to maintain and enhance natural capital, this study suggests that the supply of services and infrastructure is essential to achieve a rural renaissance beyond temporary tourism. As people are increasingly dividing their time between their urban permanent home and their rural second home, this may further suggest that there is a need to improve the connections between urban and rural areas.
\end{abstract}

Keywords: rural in-migration; urban-rural linkages; counterurbanisation; the COVID-19 pandemic

\section{Introduction}

In the wake of the COVID-19 pandemic there has been an increase in interest from city residents wanting to relocate to the countryside. Restrictions appears to have driven and may still be driving more households to migrate out of towns and cities across Europe, North America and Russia [1-3]. As social distancing restrictions and isolation has forced a great part of the global population to stay at home for longer periods of time, the access to green space and nature has become an inaccessible luxury for many. The forceful increase of households that sought to 'counterurbanise' during the pandemic was referred to by Malatzky et al. as a "disaster gentrification", highlighting the temporality of this change. Although these may be temporary changes, with people seeking to short-term 'counterurbanise', they could also represent a possibility for regrowth in rural communities.

Alongside the emergence of the crises, opportunities for rural territories have been widely discussed in newspapers all across Europe [4-6]. In Sweden the measures during the pandemic were not as strict as in many other countries, as there were never any severe lockdowns or mobility restrictions. Still, there has been a discussion whether this will lead to an increased counterurbanisation similar to the 1970s cultural movement Gröna vågen, which translates to the Green Wave, an important cultural marker where young families chose to move to the countryside [7]. The pandemic has made many people dream about access to green areas and larger private spaces, not unlike the 1970s moment. Remote working has opened new doors, exposing an alternative future for many workers and providing increased flexibility to their life situations. Taking this into consideration, it could be a substantial opportunity to repopulate and regenerate rural areas all around the globe [8]. The demand for green residential space as a motivational pull for in-migration to 
rural areas, could be viewed as a strength to further build on. As emphasised in the EU Biodiversity Strategy for 2030, "the recent COVID-19 pandemic makes the need to protect and restore nature all the more urgent, the pandemic is raising awareness of the links between our own health and the health of ecosystems" [9], and this could also be viewed as a moment to invest in rural landscapes. This should unmistakably be a planned process, as the COVID-19 pandemic may cause a widening of social inequalities since mainly wealthy urbanites, who maybe already have access to a second home in the countryside, have had the opportunity to relocate to rural areas during the pandemic. Though possibly an opportunity for a true rural renaissance, it could also trigger unwanted socio-economic inequalities and displacement in fragile locales.

Much of the ongoing debate on possible rural changes during and beyond the COVID-19 pandemic has been based on occasional observations, qualified guesses, or summaries of newspaper articles [1]. Deriving from this notion, this study seeks to understand what effects the COVID-19 pandemic may have caused, by studying a rural area in Sweden that already is exposed to the pressure of tourists and second-homeowners. The article aims to look at the increase of in-migration to rural areas and the possible motivations behind this relocation. In the introduction, lines are drawn between rural in-migration motivations and attractive landscapes. The second section looks at how COVID-19 may be a driver and enabling condition for rural regeneration and in-migration. In the methodology and the findings, the Swedish case study is introduced. Through focus group meetings and census statistics, it looks at the possible effects that the increasing interest in the countryside has had throughout the last one and a half years in the Swedish case study. Based on the findings, this study further makes suggestions beyond the ongoing pandemic and how local authorities could possibility build further on this.

\section{Conceptualising the Role of the Landscape in Rural In-Migration}

As a result of a long urban focus, counterurbanisation and post-urban in-migration into rural areas has not necessarily been in the spotlight within the field of planning. Nonetheless, there has been emerging research for the last decade on the topic. Works in the UK [10-18], North America [19-23], Australia [24], and China [25-27] have demonstrated the migration of comparatively wealthy urbanites into rural areas, in search of rural lifestyles.

Studies suggest that rural in-migrants are often attracted by specific rural amenities, particularly those associated with the natural environments and access to private space. Along these lines, Phillip and Smith coined the term "greenification", arguing that certain rural in-migration is stimulated by "the demand for, and perception of, "green" residential space" [10]. The importance of demand for green amenity and space in rural in-migration processes has been continuously explored [17,23,28-31], where for example, Argent et al. calls this amenity driven in-migration. Post-urban migration into rural locales can be connected to appealing landscapes and cultural and countercultural trends where the focus is rather on achieving a certain lifestyle. In contrast to an urban lifestyle, a rural life is often connected to certain ideas of a simpler life, free from stress and societal pressures-a rural idyll to which many aspire [32]. The "rural idyll" can offer land-based recreational activities, an opportunity to reconnect with our rural past and thereby provide a higher life quality set in a visually attractive landscape $[16,17,33,34]$. In a study by Richard et al., the sense of freedom and lack of visual obstacles was also highlighted with the idea or rurality [31]. Post-urban in-migration thereby often occurs in more aesthetically appealing parts of the countryside which offer a backdrop to the desired idyll.

\section{The COVID-19 Pandemic as a Possible Reaction-Driven Incitement for a Rural Renaissance}

During the COVID-19 pandemic, connections have been drawn between pollution and density, feeding a discussion on how high urban density may contribute to the spread of the virus [35,36]. As a reaction, the countryside has for some taken the shape of a shelter from disease - a means of maintaining physical and mental health—or as Shucksmith argues, "as 
a vision of a good place to live or as a repository of values" [32]. Indeed, urban inhabitants with adequate means moved to their second homes during longer periods of the COVID-19 pandemic to enjoy the comfort of private space and a possible increased sense of freedom. Comparatively, wealthy urbanites migrating to the countryside, both seasonally and fulltime, in search of a rural lifestyle and recreation is not something new [3,8]. Yet latent tensions between urban and rural dwellers surfaced in many areas, beyond the seasonal pressures related to local services, e.g., congested roads and overwhelmed water supplies. These could almost be considered relatively mild inconveniences as rural doctors and hospitals were not equipped to deal with the unfolding crisis and increased pressure [1,3].

The COVID-19 pandemic is possibly an enabling condition of the in-migration of middle-class migrants into specific locales and accordingly, the interest in investing in rural property increased during 2020. Across the UK, inquiries about buying a home in a village jumped by $126 \%$ from the year before $(B B C, 2020)$ and a report from the Office of National Statistics suggests that 1.15 million people are considering 'leaving [the] city to escape to the country or coast' $[37,38]$. In a Swedish survey, a third of those interviewed said that their living preferences have changed during the pandemic whereas every third person had changed their housing preferences since the pandemic. A total of $5 \%$ would like to relocate to the countryside full-time from their urban homes [39].

The COVID-19 pandemic may not cause a rural renaissance but might accelerate already ongoing cultural trends. A 2018 book called, City Quitters, portrays creative pioneers pursuing post-urban life, with the aim to spot new patterns in people's attitudes before they develop into mainstream concepts, when there is no longer a need to make a choice between rural living and a professional job thanks to technology [40]. Another aspect of the rural lifestyle that was highlighted during the pandemic was an increased awareness of locally produced products, while food insecurity was made more aware of due to food disruption in cities [41-44]. On social media, the romanticisation and longing for the countryside, green space and nature, has resulted in a phenomenon with a specific a hashtag-cottagecore-a trend that has slowly become the standout aesthetic of the 2020 according to the BBC [45].

In accordance with the initial ideas behind the Green Wave, the countryside could be connected also to an aspiration of a more sustainable life, on a household level as well as on a larger scale. In a time of climate change in parallel with worries regarding the growing intensification of the productive countryside, similar ideas as during the Green Wave have arguably emerged [46]. It was also shown during the pandemic that more intensively used landscapes showed higher numbers of infection during the pandemic [36]. As more willpower and pressure is put on the countryside, it is important to carefully plan and steer the changes occurring in the countryside, ensuring a sustainable growth and in-migration that encompasses economic, social, cultural, and environmental aspects.

It can be said that the COVID-19 pandemic may, just as cultural and countercultural trends and appealing landscapes do, contribute to rural in-migration. Human geographer Sutherland identifies a number of motivations for post-urban in-migration to rural locales, among these being the abovementioned trends and aesthetic landscapes, but also land access, household mobility, and infrastructure, as important factors [17]. Given the circumstances and the motivations behind relocation during the pandemic, migration to rural areas during the COVID-19 pandemic could be classified as a reaction-driven condition, motivated by "disaster" [47]. Besides the underlying (I) enabling conditions mentioned above, in-migration is, according to Sutherland, also driven by (II) individuals and households who want to pursue a certain idea, as well as (III) the construction of attractive rural space that is tangibly made available by property developers, estate agents, or even authorities. A combination of these three factors creates a driver for migration into rural areas. 


\section{Methodology}

The findings and analysis presented in this paper are part of a larger research project on the island of Gotland, Sweden, which is assessing the processes of in-migration and landscape change within the local community. The findings presented are derived from four datasets, the first from a traditional data analysis based on traditional data sources such as census data and real estate prices that were collected for the entire island. It further looked at the building permits that have been approved on the island since 2010 and compared it to how many residents there are. The other two datasets are based on perception data gathered through one survey and focus group meetings that were undertaken during 2021.

The empirical analysis focuses on three agricultural areas on Gotland. Three coastal zones have been recognised by the local authorities to be exposed to the high pressure of tourism and part-time residency as they are considered among the most attractive places both to visit, and live full- and part-time in, on the island. These areas are located as remotely as possible from the only city, Visby, on the island. This confirms what has been suggested in previous research on rural in-migration studies, e.g., that rural in-migration of wealthy urbanities tends to manifest in the most remote sites, such as individual farms and hamlets [16]. The territorial size of Gotland is $3140 \mathrm{~km}^{2}$ and it was up until 1951 ordered into 92 municipalities. There are today 60,124 inhabitants within administratively both a municipality and a region. Therefore, statistics are generally gathered for all of Gotland and local-based data is harder to access; however, the surveys and focus group meetings took place in three selected areas (see Figure 1) [48,49]:

- Östergarnslandet: A peninsula, located around $40 \mathrm{~min}$ from the city. The peninsula is experiencing a high percentage of part-time residential property estimated to be $68.8 \%$ of all housing. Property prices were also estimated to the be the second highest in the rural parts of the region. Östergarnslandet has the lowest average age (53.77 years) out of the selected areas; however, it still has an age average that is average of 8.77 years higher than the whole island.

- Sudret: A peninsula, located around $80 \mathrm{~min}$ from the city. The peninsula is experiencing a high percentage of part-time residential property estimated to be $66.7 \%$ of all housing. Property prices were also estimated to the be the third highest in the region. In Sudret the average age is 54.47 years.

- Fårö: A small island reached by a transportation ferry. The island is located about 1-1.5 $\mathrm{h}$ from the city depending on the ferry. The small island is experiencing a high percentage of part-time residential property estimated to be $74.5 \%$ of all housing. Property prices were also estimated to be the highest in the rural parts of the region. Property prices on Fårö were only exceeded by those of the inner-city in Visby. Fårö holds both the highest average age and also has had the most evident increase over the last 20 years. There is an average age of 57.46 years, which has increased by 11.13 years since 2000 .

It must be noted that the development in the case study area is highly affected by second-home ownership, which is far from new in this setting, nor specific to Sweden. Recreational second-home ownership has a lengthy heritage in Scandinavia, where recent estimates suggest that more than half of the population (54\%) have access to a second home [50] and is a prominent feature in Swedish society. Second homes have traditionally been small houses that are not designed to be lived in all year round [51] and are often located in more amendable parts of the landscape with a higher accessibility to nature, e.g., following the coastline or mountains, in accordance with the case study areas. Secondhome ownership is also a growing phenomenon around Europe and North America [23,52]. From this point of view, information and dialogue are important aspects not only involving temporary inhabitants in the creation of a local society [50]. Therefore, second-homeowners were also invited to take part in the survey and focus group discussions. 


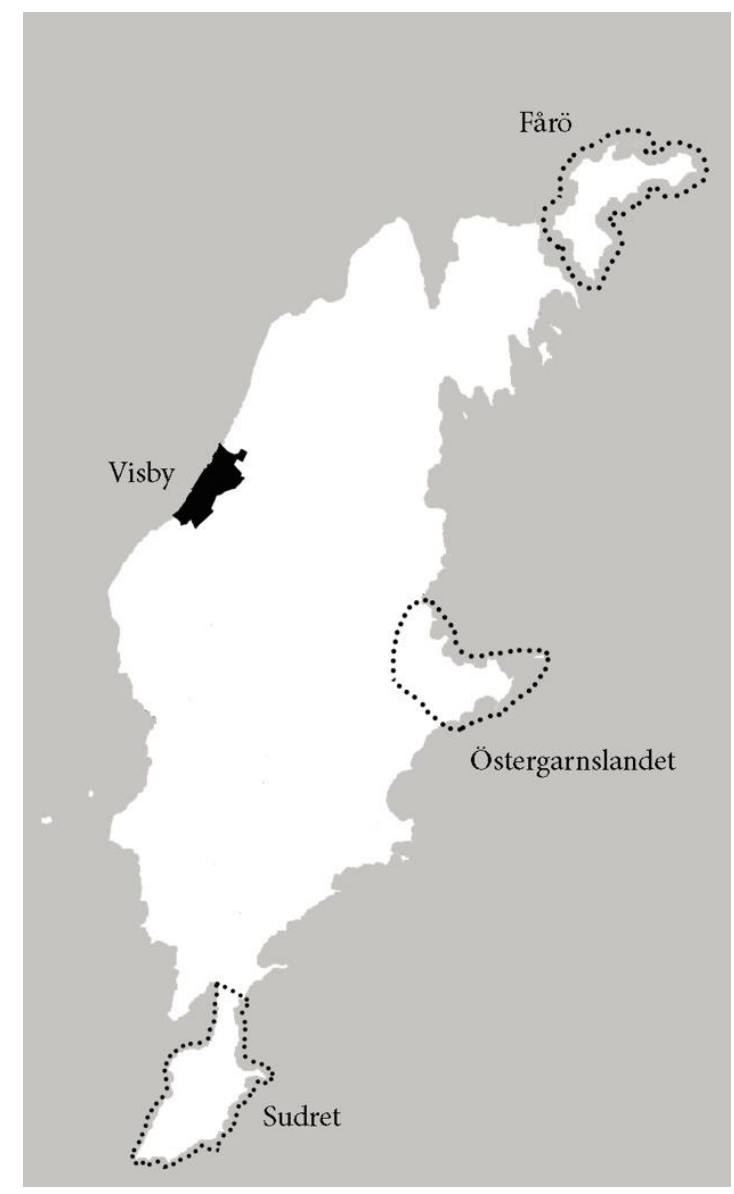

Figure 1. Map showing the case study area in Sweden. Visby, the only city, is highlighted on the west side (authors own elaboration).

This study has also looked at property prices in the study area since the beginning of the pandemic. All properties in Sweden have been given an estimated value by tax authorities based on sold properties in the nearby area in recent years. The estimated value is used for tax, insurance, and loan reasons, but can also be useful to understand rapid price development. To calculate the real estate price development, this study uses the purchase price coefficient, which is the ratio between the purchase price and the assessed value of the transferred properties. By using this method, it is possible to define how much more than the assessed value of a property a buyer has paid [53]. Yearly statistics are gathered at the end of the year and, therefore, the final sum of 2021 could not be collected when this paper was written.

The focus group interviews and questionnaires were conducted in Swedish. The questionnaire received complete responses from 129 people recruited in the three areas, which had a total of 2234 inhabitants in 2020 [49]. Forty-six of these people had their permanent residency in the area. Before participating in the questionnaire, all participants agreed with a consent form which informed them of their privacy, in line with the GDPR and the University of Bologna ethic regulations for data collection. Moreover, three in-presence workshops were organised in the same areas, with a total participation of 24 people. The participants age varied between 28 and 83 years old. In both studies, interviews were undertaken with as wide a range of inhabitants or part-time residents as possible. The workshop's participants and the interviewees were reached through local social media pages, and through short project introductions during local meetings such as the ones organised by the local history society and the farmers' association. The workshops and interviews were both recorded and transcribed in full and analysed using NVIVO qualitative data software. For this paper, transcripts from the datasets were analysed, with the 
text grouped into themes based on evidence of changes due to rural in-migration: land price, housing price, infrastructure change, external capital investment, in-migration from urban areas, decision-making processes, landscape change, and displacement of people and natural environments. In accordance with the GDPR, all participants were asked and agreed to being recorded for research purposes. Quotations have been anonymised in order to protect the delegates' privacy. Direct quotations in the text represent the authors' translations from Swedish.

\section{Findings}

\subsection{The Landscape as a Pull Factor for Regrowth}

The COVID-19 pandemic has clearly shown an increased interest in green space and rural living in general. This is not a new cultural phenomenon but well-established as a driver of counterurbanisation. Some of the focus group delegates moved to the study areas during the 1970s and the Green Wave period:

"I've been waiting for a renaissance, for there to be a new "group" arriving. Maybe now is the time: I've talked to some people and yes, young people come here but they move to the town [Visby], they do not actually come here. But now with this connection [fibre-optics network], things are possible. If you have children, it's fantastic to live like this."

(Long-term resident, 65+)

The motivation behind the Green Wave was often driven by the same motivations as suggested by the present study on rural in-migration such as a search for an alternative lifestyle, land-based recreational activities, or a quieter life (see Section on Conceptualising the Role of the Landscape in Rural In-Migration). The survey indicates that quality of life is the main reason why respondents choose to settle in the area besides using the property as a second home (see Figure 2). There was no response indicating choosing to move somewhere for education and only one response deciding to move due for work reasons. For the ones that selected other, most added a comment indicating a decision to move for nature and/or the local culture. During the workshops it was evident that there is a sense of freedom and sense of emptiness that also brings people to the place. One resident described in a positive tone what it was like when he came to Gotland 40 years ago:

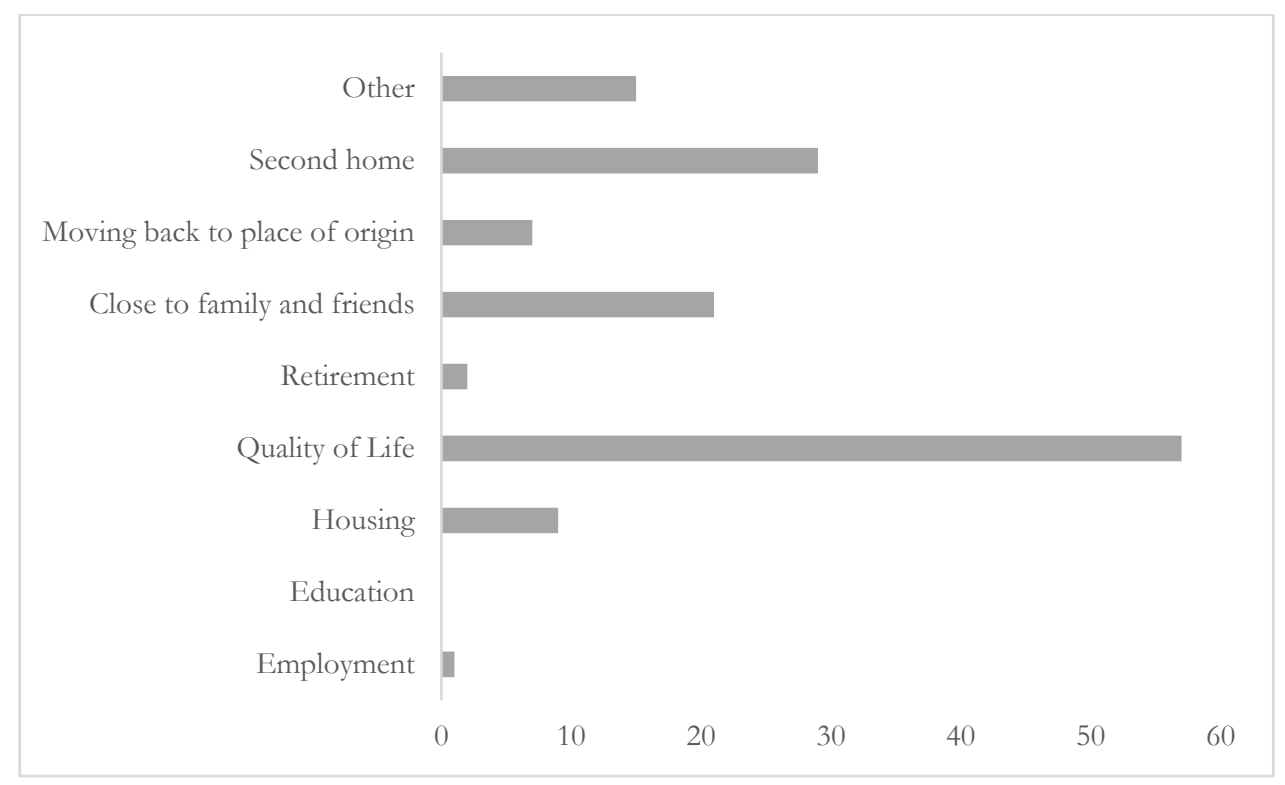

Figure 2. Graph based on survey: "What was your motivation to move to the area?".

"When I got here, it was empty. There were not people. [ ... ] Here it is free. It is a big thing. Yes, I think it is that [sense of freedom]."

(Part-time resident, 50+) 
The idea of emptiness was generally perceived as positive and pointed out by several participants in the focus group discussions. The emptiness was also referred to regarding the isolating effect caused by remoteness. This was believed to conserve the landscape and its features:

"It [the difficulty of reaching the area] has an isolating effect. It [the area] is well preserved because it's hard to get here."

(Part-time resident, 35+)

The motivations for choosing to purchase a home for living in full-time or use as a second home in the three areas appeared the same regardless of the intention of its use. There was a unity in the way of valuing the landscape and its qualities. Part-time residents were neither considered a negative impact. An increased number of part-time residents was perceived as positive by almost half of the respondents to the questionnaire $(43.1 \%)$ and neutral to almost a third (30.8\%). Many of these part-time residents spend greater periods of the year here. A report on second homes in Nordic countries suggests that second homes are primarily considered a positive asset for local inhabitants, as the second-homeowners and seasonal tourists, termed 'voluntary temporary populations' are another opportunity for positive rural development in addition to permanent residents [50]. The same was suggested in a report conducted by regional authorities on Gotland [54]. In agreement, during all focus groups discussions, a general positiveness towards part-time residents was expressed. This positive development is connected to job creation, planning of cultural activities and the provision of services. In fact, it can be argued that without a temporary population, these areas would have a weaker demand for services, and they would have fewer people to maintain the social fabric and encourage economic activities. It has been estimated that about 6000 more people have lived and worked from their part-time houses in the last year [55]:

"There are more cars outside houses. And that was noticeable already last spring. And I have spoken to people who have said "we are working from here now and it is working really well."

(In-migrant resident, 35+)

The argued in-migration, as a result of the Green Wave during the 1970s on Gotland, did show a positive net migration in statistics from the time. Since the 1950s, there has been a decreasing population on the whole island (58,995 inhabitants in 1950). Gotland has shown a slow regrowth since the 1990s, reaching approximately the same numbers as 50 years before in the year $2000(57,313)$. Since 2000, the number of inhabitants has remained stable (around 57,500); however, in 2020 the numbers hit 60,124 inhabitants which is the highest measured number of inhabitants than previously reached [56]. Simultaneously, the number of tourists is rapidly increasing. In 2020 there were reported to be more tourists than usual, although it was suggested not to travel [57]. During the summer of 2021, 76,000 people were visiting the island at once which were the highest numbers ever shown [58]. For the survey participants, there is a clear awareness of this increased tourism; however, it is not necessarily perceived as being negative, with about as many people replying that they view it as something positive. It was noted though both in the survey and by the focus group participants that during the pandemic, there has been a noticeably higher number of camper vans and cars. Although tourism per se was not perceived as negative, the camper vans and the increased traffic were viewed as harmful, especially in relation to the landscape picture. What was further noted was that tourists tended to spread out to a larger extent. Especially in areas that previously had seemed private and/or less commonly known, tourists had found their way:

"There are more people coming to learn more about nature where I work. But a lot of people do not seem to know how to behave in nature. They tell me things that they've done or where they've been, and these are not good things in accordance with how one should behave in nature." 


\section{(Long-term resident, 50+)}

Besides a larger presence of part-time residents for a longer period of the year, several focus group participants had noticed an increase in short-term tourist stays being more spread out. The tourist season seems to have been prolonged compared to previous years:

"We are used to tourists this time of the year. Maybe not this much. Now it is almost all day around. If you can put it like that. Usually this is the day when it (the tourist season) is all over, almost like cutting something off. There is usually literally no one out here. But this year...."

(Long-term resident, 50+)

\subsection{An Inaccessible Housing Situation}

In a report on the housing market, regional authorities recognised that the pandemic had an effect on the housing market which has especially struck already vulnerable citizens such as young people, elderly and migrants [59]. As a response to the increasing number of visitors, residents, and part-time residents, the housing market has shifted throughout the years. Figure 3 shows that in 2001, both a part-time residence and any other type of property would be sold for about half the present estimated value. It should also be noted that the prices of year-round properties were closely estimated to those of part-time housing. In 2002, the prices of a second home (0.52) were lower than a full-time house (0.58), and since then second homes have exceeded full-time residences in pricing. In 2007, housing for both types of occupancy exceeded the estimated value for the first time. From the mid-2010s housing prices started to increase quite rapidly and in 2019, second homes were sold for more than double their estimated value (2.11) while residential properties were sold for notably less (1.8).

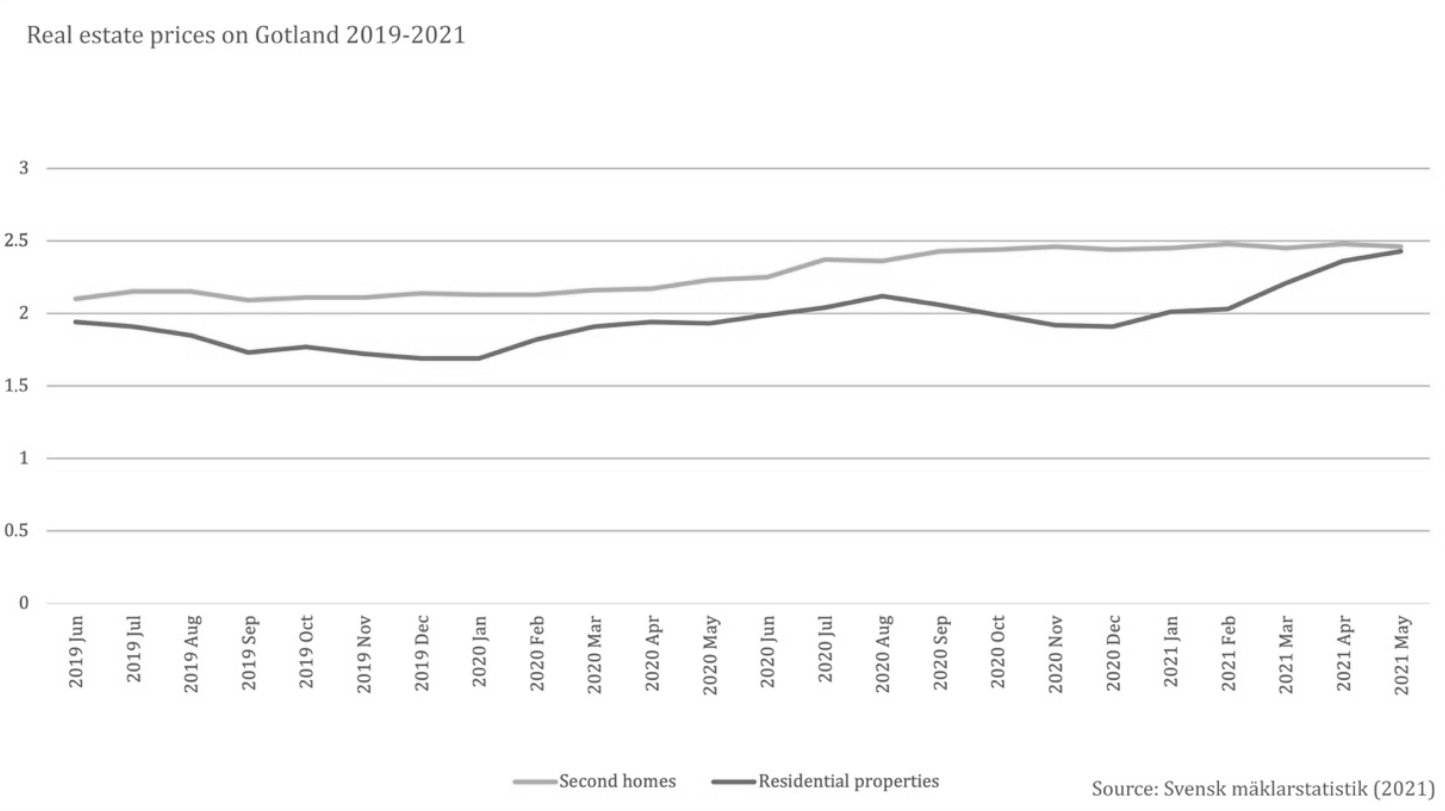

Figure 3. Increase in housing prices for the last 20 years: 2001-2020 (authors own elaboration based on statics from Swedish real estate statistics [60]).

Figure 4 shows a closer look at the evolution of the housing market on Gotland over a two-year course, from June 2019 until May 2021. Part-time houses show a stable increase over the two-year period moving from 2.1 to 2.46. Residential properties seemed to vary more over the year, decreasing during the winter months for both years, while prices increased during the spring and summer of 2020 and 2021. The prices of residential properties rose from 1.94 to 2.43 over the period of mid-2019 to mid-2021. With reference to Figure 4 , the numbers indicate an equal interest in the purchase of residential properties 
and part-time houses. There was no obvious increase in the number of sold properties between 2019 and 2021 [60]. The difficulty for the local population to invest in housing, could result in younger people having to leave their small villages, and instead move to cities [33]. This inaccessibility to the housing market and increasing of the ages of residents were present in both the survey and during the focus group discussion and was generally found worrying:

Real estate prices on Gotland 2001 - 2020

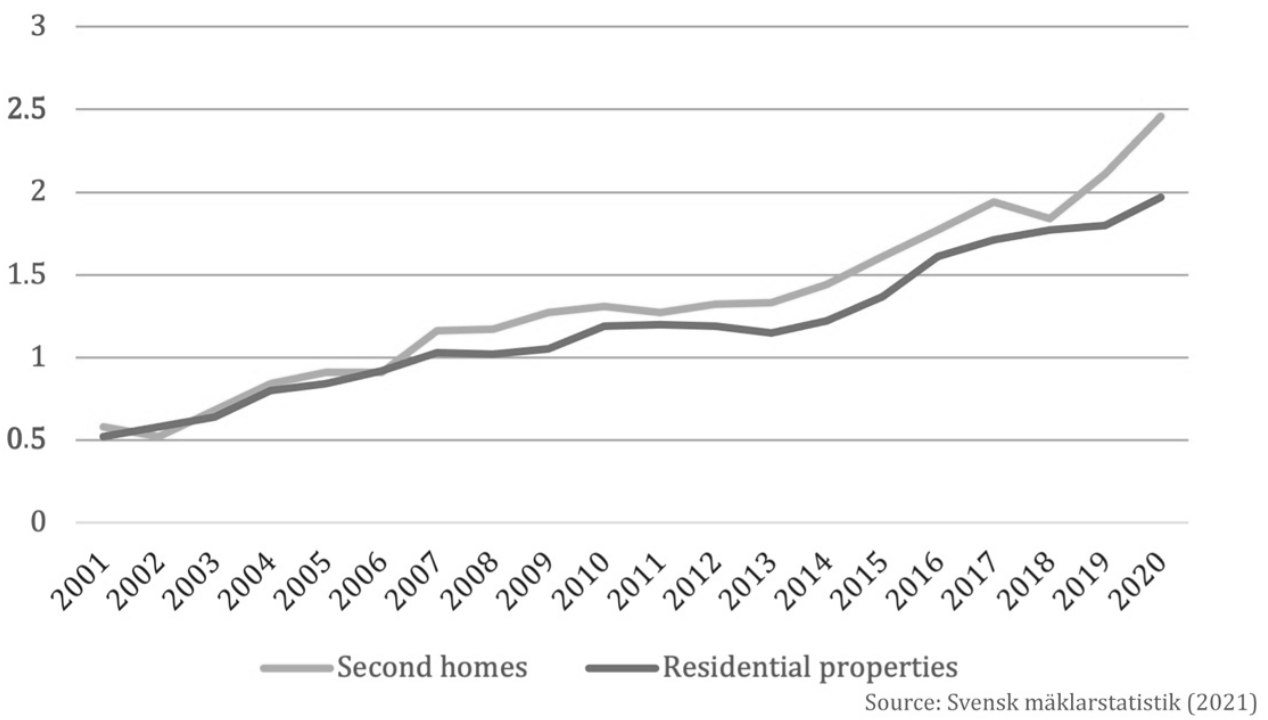

Figure 4. Increase in housing prices for the 18 months: June 2019-May 2021 (authors own elaboration based on statics from Swedish real estate statistics [60]).

"Housing is too expensive here for young people. We were many that came during the last green wave, and this may be another one. But I've been speaking with people and the younger people are moving to town [Visby], not here."

(Long-term resident, 65+)

"the problem is finding somewhere to live ... that's what it is ... that it is too expensive."

(Long-term resident, 65+)

"I must say that it is a very strange age composition here. Surely, there are families during the summer holidays. But then, there are only elderly left."

(Part-time resident, 50+)

The new turns that the delegates of the focus groups could see was believed to have changed in the last couple of years. Although tourism and second-home ownership were not perceived as negative in themselves, as acknowledged in the previous section, there was a consistent worry that these would have a devastating impact in the future. The changing climate needed to be navigated to not cause further displacement:

"I am afraid of where we are heading. I am myself a part of the mass tourism. That is undeniable. But at the same time, it must be steered somehow."

(Part-time resident, 50+)

\subsection{Infrastructure and Service Could Open New Doors}

The possibility to reside in the countryside, both temporarily and full-time, is suggested to be a result of improved infrastructure such as mobility, work and living situation: 
"We have a completely new infrastructure that opens new doors. During the pandemic now, there are many who are here all year around and work and live, even though they may have their office in Stockholm or other cities. So that's just the start of something, maybe ... these are opportunities that now we have thanks to the new fibre-optic connection, solar panels, and the desalination system."

(Part-time resident, 25+)

In the long-term vision for rural areas in Europe, the European Commission (EC) claim that connectivity is a human right today that goes beyond rural development programmes. They suggest that there could be a tax on global IT firms which would allocate money to those without internet connection [61]. In 2017 fibre-optic networks had been installed over the island, connecting the most remote areas, and had at the time the highest connectivity in the country, exceeding connectivity even in the bigger cities [62]. It was the result from local initiatives, building on a bottom-up approach, where locals organised paying a common fee to connect. One workshop delegate had chosen to work from his second home during 2020:

"[name] was here until Saint Lucy's Day since we have better WIFI connection here than in central Stockholm. With WIFI you can be connected to the entire world from here. But you can also go down to the beach. That is something one does not have in a city."

(Part-time resident, 65+)

Along the same line, a local non-profit organisation pushed through a desalination system, which was the biggest one in Sweden at the time, in one of the locales. The system has a capacity of 450 households, and 350 households have so far signed up whereas 265 of these have already installed the system. An estimated $70 \%$ of these households are not for permanent use meaning that the system will only be fully utilised for a few weeks each year. Authorities recognised the possibilities of the system, which has supported the possibilities to build "new residential and part-time properties" [63]. Besides saving the water supply for households that were fully dependent, this has also created many economic opportunities for local landowners to make a profit of selling their land:

"That's why we could sell land, there was water and sewage, fibre-optic internet connection, electricity, everything. This was not there five years ago. Then we couldn't have sold it, in this way ... but we have to be careful with the housing development. Densification where it is suitable but no more than this ...."

(Long-term resident, 65+)

The decency of access to a car as a weak spot for rural communities is something relevant all over Europe [61]. In accordance, transport infrastructure was also highlighted during the workshops. It is not only the time it takes to reach these isolated areas-in the most northern case area it requires a smaller transportation ferry of only a few minutesbut the weaknesses lie in the lack of reliance on services such as timing and also pricing. The only means of reaching Gotland is via ferry or airplane, where the prices of transport infrastructure to the mainland have manifested in public demonstrations for the last decades [64]. This does not only affect the mobility of reaching the island, but may also lead to an exclusion of people with less economic means:

"If it wasn't for the transportation, one would be here much more ... given also better prices... it is cheaper for a family to go on holidays abroad than to come here. Therefore, there are only people with money that can get here."

(Part-time resident, 65+)

On one side, there is an improved and increased number of infrastructures and services, supported by bottom-up approaches. At the same time, there can be challenges in adapting infrastructures and services to larger flows of temporary inhabitants [65]. Since 2010, 2184 new houses have been granted building permits. Of these, 410 are located in the case study areas. The number of granted building permits amounts to a total of 410: Fårö, 
168; Östergarnslandet, 134 ; and Sudret, 108 . In about $10 \%$ of these households, someone maintains a permanent residence, while $90 \%$ are used as second homes. Alike other rural areas, tax revenues from second homes, whose owners have their residency somewhere else, can represent a burden on local services [33,52]. Certain types of infrastructure are exceeding urban standards (e.g., digital connectivity); however, under the 'Shaping Europe's Digital Future' strategy, the European Commission notes that it is important that although digitalisation is an opportunity for businesses and entrepreneurship, the benefits must extend to all those living in rural areas [66]. At the same time, a low number of inhabitants and noticeable ageing of the population is seriously threatening or has already forced local schools in the locales to close. The types of services and infrastructure that were shown to be improved were often led by bottom-up initiatives, mirroring the philosophy of the 30-year-old EU LEADER method aimed at the development of rural areas [67]. Many of those present in the focus group meetings were themselves active in various non-profit organisations. Within these organisations various groups within the local community were represented, where non-residential members were believed to be an active force. It is clear from the discussions that the infrastructure and the services are fully needed for the new inhabitants as well as the part-time residents:

"People are expecting working infrastructure, even if they don't live here fulltime."

(Part-time resident, 65+)

\section{Discussion}

In accordance with observations in other rural areas across Europe and beyond during the COVID-19 pandemic, this study indicates that there has been an increased influx of visitors, for shorter or longer periods, on the Swedish island of Gotland. There was an evident increase in residential property prices over the last decade over the entire island, which indicates a larger interest in relocating to the area. In light of this, the COVID-19 pandemic could be viewed as a reaction-driven motivation for rural in-migration, beyond the identified regular incentives (see Section 1). Understandably, these recorded changes were a result of a combination of factors that are summarised and discussed below.

By looking at three areas, that are already recognised by public authorities as particularly exposed to a high rate of second-home ownership, increasing housing prices and an evident increase of population age, a pattern to understand the motivations to move to and stay in these areas was explored. Findings from this present study demonstrate, in accordance with previous understandings, that the main demand-pull for rural in-migration is found in the landscape of the three locales, both for long-term residents and for second-homeowners. There is a demand for a certain quality of life connected to the landscape which was often expressed in a sense of remoteness and "emptiness". These may be factors that might be affected by temporary tourism; however, the increased interest in the area during the pandemic and second-home ownership was not perceived as negative. It was rather thought of as an opportunity for people to rediscover the territory beyond short-term stays.

It was not only the appealing landscape that brought visitors to stay for a longer period in the area. The study showed that owing to its adequate infrastructure, moving temporarily to remote areas on Gotland was made possible, e.g., an exceptionally good digital connection and a working sewage system. This suggests that even though enabling conditions such as the appealing landscapes of the case study areas could have been enhanced as a reaction to the pandemic, basic infrastructures and services are needed to make the repopulation of rural areas a reality. These services can allow people to move into, build new houses and settle long-term while continuing to work remotely. It should also be noted that increased infrastructure and services were in some cases the results of bottom-up initiatives. Although collaborations along these lines are highlighted as key in the strategic planning locally, referring to the Sustainable Development Goals [68], these initiatives are often driven by urban standards and expectations, and are funded privately by urban salaries. Some types of infrastructure may only enable longer stays for more 
mobile occupants but not for full-time residents. As their residency remains in their urban home, the economic capital invested into the settlements thus remain primarily urban. This causes a bad spiral where tax money cannot be invested into required services such as schools. At the same time urban families cannot imagine settling full-time in an area that cannot provide education for their children, which is a known important pull factor for families to relocate to the countryside [69].

Some may argue that this will be the technology-enabled future that has been imagined for decades in which technology allows us to work less and more flexibly, including working from home. Rural in-migration shows that it is possible with remote working technologies available, but this is mainly available to white-collar workers. Counterurbanisation and heavy in-migration flows would be assumed to lead to the gentrification of rural communities, resulting in a displacement of people, traditions, and natural environments. It was evident from the study, that during the 18 so far most critical months of the pandemic, housing prices did reach striking numbers. For example, higher housing and land prices will over time restrict the capacity of agriculture to adjust to maintain its competitiveness. Thereby, it inevitably gives way to a less commercial agricultural future $[70,71]$. If key workers of all types cannot afford to live and work in rural areas, there are knock-on consequences for social wellbeing and service provision. Going forward from here, technology-enabled rural in-migration could be "geographically and socially uneven" in its application if not planned for. Local authorities must find ways to aid locally based enterprises and job opportunities. This could be promoted by networks of local actors, with cooperation through a common vision. There are various governance strategies (e.g., territorial social responsibility) that highlight the importance of creating common values and increase cooperation among enterprises [71,72].

The study suggested that part-time residents were spending more time in their second homes during the pandemic. It has been shown earlier that people increasingly divide their time between their urban permanent home and their rural second home in Nordic countries [50]. Allowing people to turn second homes into permanent homes has been mentioned as a possible solution to the housing shortage in Sweden; however, as human geographer Mamova et al. points out, a key value of a second home lays in its position as a retreat from urban life [52]. Important cultural and social capitals, such as the sense of freedom that was touched upon by many part-time residents during the workshops, are generated through these part-time residencies. Second homes would thereby lose their social and cultural value if they were to become permanent housing for their current occupants. It was evident from the focus group discussions and the survey that secondhome ownership was not perceived as a negative factor.

What cannot be known from this study is if the increasing number of inhabitants on the whole island is temporary; however, the increased demand for rural housing and green space is nonetheless visible which is something that governments and authorities should take advantage of. Government and local authorities could invest in these areas to make the most of the reaction-driven migration, both in supporting inhabitants and in-migrants, but also in establishing services that can support all-year-around living. The rural communities on Fårö, Östergarnslandet and Sudret need to access affordable housing as the countryside and accessible nature should not be a luxury. Local authorities should invest in housing that meets the needs of settlements, including affordable housing, otherwise the already existing tendencies may lead to gentrification and further displacement. This could also be seen as an important moment for authorities to invest in infrastructure that supports the increased interest in nature-based recreation and to protect values in the landscape. As these results reveal, the landscape was shown to be a main enabling factor, and they show there is value in retaining and attracting new visitors and inhabitants. Economic investments by local authorities into protecting nature and local values, would ensure a better capacity and resilience in increased seasonal flows. This would highlight the importance of caring and valuing our surroundings, and thereby lead the way for future initiatives. In addition, second- homeowners' commitment and contribution should not 
be underestimated but cared for by authorities. With this in mind, this study suggests there is a need to rethink rurality and plan for a multifunctional use of the land, where also second home mobility and the flows of seasonal tourists could be supported and no longer perceived as urban nor rural phenomena.

\section{Conclusions}

The COVID-19 pandemic could be viewed as a reaction-driven motivation for rural in-migration, beyond the identified regular incentives. In particular, three specific study areas on the island of Gotland have been under exposure to increasing tourism, increasing numbers of second homes, and an increasing population age. Findings from the present study demonstrate, in accordance with previous understandings, that the main demandpull for rural in-migration is found in the landscape of the three locales, both for long-term residents and second-homeowners. There is a demand for a certain quality of life connected to the landscape which was often expressed in a sense of remoteness and "emptiness". The study showed that owing to its adequate infrastructure (e.g., an exceptionally good digital connection and a working sewage system), moving temporarily to remote areas on Gotland was made possible. This suggests that even though enabling conditions such as the appealing landscapes of the case study areas could have been enhanced as a reaction to the pandemic, basic infrastructures and services are still needed to make the repopulation of rural areas a reality.

Heavy in-migration flows, and second-home ownership could lead to the gentrification process, resulting in a displacement of people, traditions, and natural environments. It was evident from the study that there was a sharp increase in housing prices on a Swedish island that was already experiencing a staggering rise. The increased demand for rural housing and green space is nonetheless visible which is something that governments and authorities should take advantage of. In accordance with the recent EU biodiversity strategy, there is an increased need to protect and restore nature, due to both the growing pressure but also to the attraction for people to live in these areas, as nature was evidently the main reason to move to a certain locale. As a result of shifting societal norms, this could possibly encourage an evolution in the future of rural communities that have suffered from outmigration. It is necessary to maintain and enhance natural capital, as it provides the main pull factor for in-migration; however, this study suggests that the supply of services and infrastructure is essential to achieve a rural renaissance beyond temporary tourism and that to this aim, an integrated urban and regional plan is needed to ensure the right balance between landscape enrichment and supporting rural communities.

With the improved infrastructure standards, the lines between urban and rural is blurred. This may suggest that there is a need to speak of urban-rural linkages rather than a division.

\section{Limitations and Recommendations for Future Studies}

The main limitation of this research primarily lays in the lack of data as the COVID-19 pandemic is still ongoing. In the future, it will be more evident what impact the pandemic had and might have later. This study may lay a foundation and incitement to follow the development driven by the pandemic in these three areas on Gotland.

Another detected limitation was that while the participants to the workshops and questionnaires were of a varied age and sex, they were predominantly part-time residents. Most of them had found the workshop invitations and the questionnaires via local social media groups and were already engaged in questions regarding local development. It could be relevant to pinpoint a variation of residents to explore the topic further and especially to ensure a wider point of view.

As this study was limited to only a small area in Sweden, it could be interesting to compare the outcomes shown here to other rural areas. For future studies it would be of interest to detect similar patterns and results taking place in other countries. 
Author Contributions: Conceptualization, H.E.Å.; methodology, H.E.Å.; software, H.E.Å.; validation, H.E.Å. and S.T.; formal analysis, H.E.Å.; investigation, H.E.Å.; resources, H.E.Å.; writingoriginal draft preparation, H.E.Å.; writing—review and editing, H.E.Å. and S.T.; visualisation, H.E.Å.; supervision, S.T. All authors have read and agreed to the published version of the manuscript.

Funding: This work was supported by the Marco Polo scholarship [art. 46 T.U.-D.P.R. n. 445 del 28/12/2000].

Institutional Review Board Statement: Not applicable.

Informed Consent Statement: Informed consent was obtained from all subjects involved in the study. The survey was collected according to the Privacy policy guidelines of the University of Bologna.

Data Availability Statement: Not applicable.

Conflicts of Interest: The authors declare no conflict of interest.

\section{References}

1. Pitkänen, K.; Hannonen, O.; Toso, S.; Gallent, N.; Hamiduddin, I.; Halseth, G.; Hall, C.M.; Müller, D.K.; Treivish, A.; Nefedova, T. Second homes during corona-safe or unsafe haven and for whom? Reflections from researchers around the world. FINNISH J. Tour. Res. 2020, 16, 20-39. [CrossRef]

2. de Luca, C.; Tondelli, S.; Åberg, H.E. The COVID-19 Pandemic Effects in Rural Areas. TeMA-Journal of Land Use, Mobility and Environment; Laboratory of Land Use Mobility and Environmental: Naples, Italy, 2020.

3. Gallent, N. COVID-19 and the flight to second homes. J. Town Ctry. Plan. Assoc. 2020, 89, 141-144.

4. Boström, H. Marstrand är ett Extremfall av Gentrifiering. Göteborgs-Posten. 2021. Available online: https://www.gp.se/ledare/ marstrand-\%C3\%A4r-ett-extremfall-av-gentrifiering-1.44230972 (accessed on 4 August 2021).

5. Gallione, A. L'architetto Stefano Boeri: “La Pandemia ci ha Fatto Riscoprire i Borghi Storici. Così i Piccoli Comuni Salveranno Anche le Metropoli". La Repubblica. 2021. Available online: https://www.repubblica.it/dossier/cronaca/turismo-2021/2 021/03/01/news/1_architetto_stefano_boeri_la_pandemia_ci_ha_fatto_riscoprire_i_borghi_storici_cosi_i_piccoli_comuni_ salveranno_anche_le_-289447295/ (accessed on 4 August 2021).

6. Gallagher, S. Escape to the Country: Will People Leave Cities Behind Post-Pandemic? The Independent. 2020. Available online: https:/ / www.independent.co.uk/life-style/people-leaving-cities-london-manchester-coronavirus-pandemic-lockdown-a961 2116.html (accessed on 4 August 2021).

7. Nationalencyklopedin: Gröna vågen. Available online: https://www.ne.se/uppslagsverk/encyklopedi/1\%C3\%A5ng/gr\%C3 \%B6na-v\%C3\%A5gen (accessed on 4 August 2021).

8. Zogal, V.; Domènech, A.; Emekli, G. Stay at (which) home: Second homes during and after the COVID-19 pandemic. J. Tour. Futurs. J. 2020, in press. [CrossRef]

9. European Commission. EU Biodiversity Strategy for 2030. 2020. Available online: https:/ / eur-lex.europa.eu/legal-content/EN/ TXT / ?uri=CELEX:52020DC0380 (accessed on 3 May 2021).

10. Smith, D.P.; Phillips, D.A. Socio-cultural representations of greentrified Pennine rurality. J. Rural Studes. 2001, 17, 457-469. [CrossRef]

11. Phillips, M.; Smith, D.; Brooking, H.; Duer, M. Idyllic Ruralities, Displacement and Changing Forms of Gentrification in Rural Hertfordshire, England. Doc. D'anàlisi Geogr. 2020, 66, 259-287. [CrossRef]

12. Phillips, M.; Smith, D.P. Comparative approaches to gentrification: Lessons from the rural. Dialogues Hum. Geogr. $2018,8,3-25$. [CrossRef] [PubMed]

13. Phillips, M. Differential productions of rural gentrification: Illustrations from North and South Norfolk. Geoforum 2005, 36, 477-494. [CrossRef]

14. Phillips, M. Other geographies of gentrification. Prog. Hum. Geogr. 2004, 28, 5-30. [CrossRef]

15. Phillips, M. The production, symbolization and socialization of gentrification: Impressions from two Berkshire villages. Trans. Inst. Br. Geogr. 2002, 27, 282-308. [CrossRef]

16. Stockdale, A. The diverse geographies of rural gentrification in Scotland. J. Rural Studies. 2010, 26, 31-40. [CrossRef]

17. Sutherland, L.A. Agriculture and inequalities: Gentrification in a Scottish parish. J. Rural Stud. 2019, 68, 240-250. [CrossRef]

18. Sutherland, L.A. Return of the gentleman farmer?: Conceptualising gentrification in UK agriculture. J. Rural Stud. 2012, 28, 568-576. [CrossRef]

19. Abrams, J.; Bliss, J.C. Amenity Landownership, Land Use Change, and the Re-Creation of "Working Landscapes". Soc. Nat. Resour. 2013, 26, 845-859. [CrossRef]

20. Hines, J.D. In pursuit of experience: The postindustrial gentrification of the rural American West. Ethnography 2010, 11, 285-308. [CrossRef]

21. Hines, J.D. Rural Gentrification as Permanent Tourism: The Creation of the 'New' West Archipelago as Postindustrial Cultural Space. Environ. Plan. D Soc. Space 2010, 28, 509-525. [CrossRef] 
22. Nelson, P.B.; Oberg, A.; Nelson, L. Rural gentrification and linked migration in the United States. J. Rural Stud. 2010, $26,343-352$. [CrossRef]

23. Darling, E. The city in the country: Wilderness gentrification and the rent gap. Environ. Plan. A 2005, 37, 1015-1032. [CrossRef]

24. Argent, N.; Tonts, M.; Jones, R.; Holmes, J. Rural Amenity and Rural Change in Temperate Australia: Implications for Development and Sustainability. Rev. Za Geogr.-J. Geogr. 2009, 4, 15-28.

25. Qian, J.; He, S.; Liu, L. Aestheticisation, rent-seeking, and rural gentrification amidst China's rapid urbanisation: The case of Xiaozhou village, Guangzhou. J. Rural Studies 2013, 32, 331-345. [CrossRef]

26. Wang, S.; Chen, S.; Xu, H. Resident attitudes towards dark tourism, a perspective of place-based identity motives. Curr. Issues Tour. 2019, 22, 1601-1616. [CrossRef]

27. Zhao, Y. When guesthouse meets home: The time-space of rural gentrification in southwest China. Geoforum 2019, 100, 60-67. [CrossRef]

28. Halliday, J.; Coombes, M. In search of counterurbanisation: Some evidence from Devon on the relationship between patterns of migration and motivation. J. Rural Stud. 1995, 11, 433-446. [CrossRef]

29. Paquette, S.; Domon, G. Changing ruralities, changing landscapes: Exploring social recomposition using a multi-scale approach. J. Rural Stud. 2003, 19, 425-444. [CrossRef]

30. Phillips, M.; Page, S.; Saratsi, E.; Tansey, K.; Moore, K. Diversity, scale and green landscapes in the gentrification process: Traversing ecological and social science perspectives. Appl. Geogr. 2008, 28, 54-76. [CrossRef]

31. Richard, F.; Dellier, J.; Tommasi, G. Migration, environment and rural gentrification in the Limousin mountains. J. Alp. Res. 2014, 102. [CrossRef]

32. Shucksmith, M. Re-imagining the rural: From rural idyll to Good Countryside. J. Rural Stud. 2018, 59, 163-172. [CrossRef]

33. Solana-Solana, M. Rural gentrification in Catalonia, Spain: A case study of migration, social change and conflicts in the Empordanet area. Geoforum 2010, 41, 508-517. [CrossRef]

34. Stockdale, A. Migration: Pre-requisite for rural economic regeneration? J. Rural Studies 2006, 22, 354-366. [CrossRef]

35. Cole, M.A.; Ozgen, C.; Strobl, E. Air Pollution Exposure and COVID-19. Environ. Resour. Econ. 2020, 76, 581-610. [CrossRef] [PubMed]

36. Agnoletti, M.; Manganelli, S.; Piras, F. COVID-19 and rural landscape: The case of Italy. Landsc. Urban Plan. 2020, $204,103955$. [CrossRef]

37. Smith, D.P.; Phillips, M.; Culora, A.; Kinton, C. The mobilities and immobilities of rural gentrification: Staying put or moving on? Popul. Space Place 2021, 27, 1-12. [CrossRef]

38. Daily Mail COVID Exodus Begins: One in Ten City Dwellers Plan to Move to the Country or Coast I Daily Mail Online. Available online: https:/ / www.dailymail.co.uk/news/article-8773399/Covid-exodus-begins-One-ten-city-dwellers-plan-country-coast. html (accessed on 19 August 2021).

39. Hemnet Så Vill vi bo-Efter Restriktioner och Hemmajobb-Hemnet. Available online: https://www.hemnet.se/artiklar/ bostadsmarknaden/2021/06/28/sa-vill-vi-bo-efter-restriktioner-och-hemmajobb (accessed on 6 August 2021).

40. Rosenkranz, K. City Quitters-Creative Pioneers Pursuing Post-Urban Life; Tyson, G., Ed.; Frame Publishers: Amsterdam, The Netherlands, 2018.

41. Cattivelli, V.; Rusciano, V. Social Innovation and Food Provisioning during COVID-19: The Case of Urban-Rural Initiatives in the Province of Naples. Sustainability 2020, 12, 4444. [CrossRef]

42. Lal, R. Home gardening and urban agriculture for advancing food and nutritional security in response to the COVID-19 pandemic. Food Secur. 2020, 12, 871-876. [CrossRef]

43. Sanderson, M.R. Here we are: Agriculture and Human Values in the Coronavirus (COVID-19) pandemic. Agric. Hum. Values 2020, 37, 515-516. [CrossRef] [PubMed]

44. Gordon, L.J. The COVID-19 pandemic stress the need to build resilient production ecosystems. Agric. Hum. Values 2020, 37, 645-646. [CrossRef]

45. BBC. "Cottagecore" and the Rise of the Modern Rural Fantasy-BBC Culture. Available online: https://www.bbc.com/culture/ article/20201208-cottagecore-and-the-rise-of-the-modern-rural-fantasy (accessed on 6 August 2021).

46. Sutherland, W.J. Restoring a sustainable countryside. Trends Ecol. Evol. 2002, 17, 148-150. [CrossRef]

47. Malatzky, C.; Gillespie, J.; Couch, D.L.; Cosgrave, C. Why place matters: A rurally-orientated analysis of COVID-19's differential impacts. Soc. Sci. Humanit. Open 2020, 2, 100063. [CrossRef]

48. Region Gotland. Deltidsboende $i$ Gotlands Ytterområden Innehåll; Region Gotland: Visby, Sweden, 2018.

49. Demograften. Available online: http:/ / demografen.gotland.se/ (accessed on 5 August 2021).

50. Slätmo, E.; Vestergård, L.O.; Lidmo, J. Compact Cities Trigger High Use of Second Homes in the Nordic Region; Nordregio: Stockholm, Sweden, 2019. [CrossRef]

51. The Swedish National Board of Housing, B. and P. Krav på Fritidshus_PBL Kunskapsbanken-Boverket. Available online: https:/ / www.boverket.se/sv / PBL-kunskapsbanken/regler-om-byggande/krav-pa-byggnadsverk-tomter-mm/byggnadsverk/ fritidshus / (accessed on 4 August 2021).

52. Mamonova, N.; Sutherland, L.A. Rural gentrification in Russia: Renegotiating identity, alternative food production and social tensions in the countryside. J. Rural Stud. 2015, 42, 154-165. [CrossRef] 
53. Statistiska Centralbyrån Hur Mäter Man Prisutvecklingen på Småhus? Available online: https://www.scb.se/hitta-statistik/statistikefter-amne/boende-byggande-och-bebyggelse/fastighetspriser-och-lagfarter/fastighetspriser-och-lagfarter/produktrelaterat/ Fordjupad-information/hur-mater-man-prisutvecklingen-pa-smahus/ (accessed on 6 August 2021).

54. Region Gotland. Deltidsboende i Gotlands Ytterområden; Region Gotland: Visby, Sweden, 2019.

55. Hela Gotland Gotlandsfrågor i Motionsfloden. Helagotland. Available online: https://helagotland.se/bli-prenumerant/artikel/ rg95n7ej (accessed on 10 October 2021).

56. Regionfakta Befolkningsförändring Senaste Året-Regionfakta. Available online: https:/ / www.regionfakta.com/gotlands-lan/ befolkning-och-hushall/befolkning/befolkningsforandring-senaste-aret/ (accessed on 4 July 2021).

57. Västerbottens-Kuriren Turistboom på Gotland: “Mer än på många år". Available online: https://www.vk.se/2020-07-18 / turistboom-pa-gotland-mer-an-pa-manga-ar (accessed on 4 July 2021).

58. SVT Nyheter Turistrekord på Gotland—och Fler Besökare Väntas. Available online: https://www.svt.se/nyheter/lokalt/ost/ turistrekord-pa-gotland-och-fler-besokare-vantas (accessed on 10 August 2021).

59. Länsstyrelsen i Gotlands län. Regional Bostadsmarknadsanalys Gotlands län 2021; Länsstyrelsen i Gotlands län: Gotlands län, Sweden, 2021.

60. Svensk Mäklarstatistik Bostadspriser i Gotlands län » Svensk Mäklarstatistik. Available online: https:/ / www.maklarstatistik.se/ omrade/riket/gotlands-lan/\#/ fritidshus (accessed on 4 July 2021).

61. The European Commission. A Long-Term Vision for the EU's Rural Areas-Towards Stronger, Connected, Resilient and Prosperous Rural Areas by 2040. Available online: https:/ / ec.europa.eu/info/law/better-regulation/have-your-say/initiatives/12525Rural-development-long-term-vision-for-rural-areas_en (accessed on 4 July 2021).

62. Sveriges Radio Gotland Först och Störst på Bredband 2017. Available online: https://sverigesradio.se/artikel/6726660 (accessed on 8 August 2021).

63. Region Gotland. Bräckvattenverket i Herrvik på Gotland. Available online: https:/ / www.gotland.se/91546 (accessed on 8 August 2021).

64. Aftonbladet Gotlandsupproret, Ted Ljungqvist: Båten till Gotland Måste bli Billigare-nu. Available online: https://www. aftonbladet.se/debatt/a/wEKywP/sank-priset-pa-gotlandsfarjan (accessed on 10 September 2021).

65. Slätmo, E.; Vestergård, L.O.; Lidmo, J.; Turunen, E. Urban-Rural flows from Seasonal Tourism and Second Homes Planning Challenges and Strategies in the Nordics; Nordregio: Stockhom, Sweden, 2020.

66. European Commission. Shaping Europe's Digital Future; Publications Office of the European Union: Luxembourg, 2020. [CrossRef]

67. The European Network for Rural Development. LEADER/CLLD Explained. Available online: https:/ / enrd.ec.europa.eu/leaderclld/leader-toolkit/leaderclld-explained_en (accessed on 10 October 2021).

68. Region Gotland Genomgående Perspektiv för en Hållbar Utveckling_Vårt Gotland 2040. Available online: https:/ / rus.gotland. se/?page_id=1856 (accessed on 28 October 2021).

69. Smith, D.P.; Higley, R. Circuits of education, rural gentrification, and family migration from the global city. J. Rural Stud. 2012, 28, 49-55. [CrossRef]

70. Barr, N.F.; Karunaratne, K.; Centre for Land Protection Research (Vic.). Victoria's Small Farms; Dept. Natural Resources and Environment: Bendigo, VIC, Australia, 2002; 22p.

71. Baldo, M.D. Territorial Social Responsibility and Territorial Small and Medium-Sized Enterprises. In Encyclopedia of Corporate Social Responsibility; Idowu, S.O., Capaldi, N., Zu, L., Gupta, A.D., Eds.; Springer: Berlin/Heidelberg, Germany, 2013. [CrossRef]

72. Almeida Ashley, P.; Crowther, D. Territories of Social Responsibility: Opening the Research and Policy Agenda-Patricia Almeida Ashley_Google Books; Ashgate Publishing Limited: Farnham, UK, 2012. 